\title{
Opening the 'black box': what does observational research reveal about processes and practices of governing?
}

\author{
Cate Watson $^{1}$ D . Gary Husband ${ }^{1} \cdot$ Aileen Ireland ${ }^{1}$
}

Published online: 21 February 2020

(c) The Author(s) 2020

\begin{abstract}
Despite several decades of research on governance, very little is known about processes and practices of governing and, crucially, the links between governing and organisational performance. This has led to calls to penetrate the 'black box' of the boardroom by conducting research which draws on data gathered through direct observation. Such calls, however, have so far produced a rather sparse and inchoate literature which would benefit from review in order to give shape to the field and provide direction for future research. Here, we critically examine the findings of this research, focusing on three emergent themes: (1) the extent to which empirical research supports the established theories in the field, particularly agency and stewardship theories; (2) what research says about 'good' and 'effective' governance and the relationship between them; and (3) the methodological and conceptual orientations which frame this research, and the claims made for 'processual' approaches. We conclude with an agenda for taking the field forward in order to extend knowledge and to contribute to theory around governing.
\end{abstract}

Keywords Control-collaboration paradox $\cdot$ Effective governance $\cdot$ Good governance $\cdot$ Processual research $\cdot$ Symbolic governance $\cdot$ Strategising

\section{Introduction}

The importance attached to the role of the governing board is reflected in the widespread introduction of codes of good governance in both the for-profit and not-for-profit sectors. Good governance is, however, 'a rare and unnatural act' (Taylor et al. 1996) and governing boards have been subject to criticism and censure with many examples of mismanagement attributed to the failure of governing boards to effectively oversee organisations or provide strategic direction. This apparent failure is compounded by a lack of understanding, among academics,

Cate Watson

cate.watson@stir.ac.uk

1 Faculty of Social Sciences, University of Stirling, Stirling FK9 4LA, UK 
organisations and boards alike, of what governing 'is' or the practices that attend it (Hill et al. 2016). Despite the normative assumptions underpinning the work of governing boards there is little empirical evidence which has examined what it is boards actually do. Research has focused on structures and procedures in terms of the formal constitution of entities providing accountability mechanisms (Boyd et al. 2011), with little known about the processes and practices of governing or relationships between governance, leadership and organisational aims/outcomes. Much of this research has been conducted within a positivist ethos in search of a 'global theory' which eschews fine-grained analysis and ignores the role of context and wider relations of the board (Durisin and Povone 2009). While McNulty et al. (2013, p. 183) point to a growth of qualitative studies with greater concern around the performance of boards and critique of dominant theories, particularly agency theory, they note that this still represents only a small fraction of published work. Though yielding some interesting insights into board behaviours and dynamics, much of this qualitative research has been conducted within an interpretive tradition focusing on the perspectives and experiences of board members, relying on participants' retrospective accounts gathered through semi-structured interviews. While helpful for understanding individuals' sense-making and identities in relation to governance, such studies do not capture the complexity of strategic decision-making in real time as it unfolds in meetings. In acknowledging this deficit, Cadbury (2000, p. 12) argued that,

The most useful field for further research would be into what goes on in boards ... The more that research can concentrate on boards in action, on process rather than structure, the greater the chance that research findings will be operationally relevant and acted upon.

Since Cadbury wrote this, a growing number of researchers have taken up the call to study boards in action. This paper presents a review of this research to uncover what it is that boards 'really' do. Its aim is to interrogate the field, providing a critical review and analysis of the various streams of research that have employed observational methods to study boards. The paper will be of use to academics conducting research in this and cognate areas. In this way we aim to support a research programme which will yield knowledge of use to boards, leadership and management, and policy-makers.

In doing this we identify three important themes emerging from the literature: (1) the extent to which empirical research supports the established theories in the field, particularly agency and stewardship theories; (2) what research says about 'good' and 'effective' governance and the relationship between them; and (3) the methodological and conceptual orientations which frame this research, in particular the claims made for 'processual' approaches.

The paper is set out as follows: we start by defining the scope of our review, in which we consider corporate governance in both the for-profit and not-for-profit sectors. We follow this with an overview of research in the field and present a critical analysis in relation to the three themes outlined above. Finally, we summarise the findings and we conclude with an agenda to take the field forward. 


\section{Defining the scope of the research}

While acknowledging the wider governance space within which organisations operate, this paper focuses on the key role of the board meeting in representing the formal route through which the organisation is constituted. As Samra-Fredericks (2000a, p. 251) notes, while much talk of relevance to board decisions occurs outside the boardroom 'in corridors, car parks, personal offices and the men's toilets', if it is significant it finds its way to the boardroom as this is the space in which governing is legitimised. We have included research covering both the for-profit and not-for-profit sectors, not for the purposes of comparison but in order to enlarge the pool of research from which to draw, as access to boardrooms, particularly of for-profit organisations, has proved difficult for a number of reasons (Leblanc and Schwartz 2007). As a rule of thumb, forprofits have shareholders, not-for-profits have (only) stakeholders. While we recognise that this difference has considerable implications for the governing board in relation to revenue sources, organisational values/mission and in terms of accountability, which might indeed have significant effects on the processes and practices of governing, in other respects, both for- and not-for- profits share common concerns such as strategic positioning, ensuring financial probity, planning, control, etc. (Cornforth 2004). Moreover, many of the normative assumptions surrounding not-for-profits (especially around charitable status) are unfounded since not-for-profits are very variable and some may operate in very competitive markets (Maitlis 2004). Indeed, some commentators note a convergence between governance in the for- and not-for- profit sectors as the 'new public management' has encouraged moves towards the adoption of organisational structures that mimic the commercial sector (Ashburner et al. 1996; Peck et al. 2004; Freeman and Peck 2007; Tacon and Walters 2016); conversely, for-profit organisations are now required to be heedful of their 'corporate and social responsibilities' in the pursuit of 'sustainable' governance (Huse 2005), which acknowledges wider obligations towards non-shareholder stakeholders (Bury and Leblanc 2007).

While there are clearly cognate areas of research which are relevant to the work of boards (for example, around strategy, decision-making, meetings etc.), the governing board represents a distinct scenario which justifies it as a focus for research. The governing board is a complex social mix, necessitated, according to Berle and Means' (1932) foundational work, as a result of the separation of ownership and control of an organisation. External control is presumed to be necessary in order to protect shareholders' interests, but 'outsider' status renders the function of the board problematic since most non-executive directors (NEDs) have limited knowledge of the organisation, limited time, and quite possibly limited commitment to the enterprise. This sets up some distinctive processes around the three areas of strategy, control and support/ service that are widely assumed to form the core areas of board function (Hung 1998; Korac-Kakabadse et al. 2001). 


\section{Observational research and theories of governing}

The distinct and complex nature of the work of the governing board is indicated by the range of competing/complementary theories advanced to account for it. Key among these are: agency (Eisenhardt 1989; Brennan et al. 2016), stewardship (Davis et al. 1997), managerial hegemony (Kosnik 1987), and resource dependency (Bryant and Davis 2012). Others, such as stakeholder theory (e.g., Cornforth 2004), certainly have relevance for governing, especially for not-for-profits, though they are not specific to it. Since these theories are well-covered in the literature we have not elaborated on them here. While it would be tempting to align theory with the three core areas, this would be simplistic. However, it might be reasonable to say that control is the main focus of agency theory; stewardship concerns mainly service/support but may also include a strategy role; managerial hegemony assumes board support for managerial decision making; and resource dependency is focused on service/support. It should be noted that agency theory is regarded as problematic in relation to not-for-profits which may have a number of principals with different objectives (Van Puyvelde et al. 2012). While prevalent in the literature, theories of governing are underpinned by relatively little empirical work. In particular, there is little understanding of the complex interactions severally implied. If control, strategy and support/service are assumed to be the key functions of boards then this gives rise to a complex set of potentially paradoxical tensions around control and collaboration (Sundaramurthy and Lewis 2003; Smith and Lewis 2011) which have yet to be adequately examined through an empirical lens. In addition to these three instrumental aspects of governing, others have alluded to the symbolic role of boards in organisations, drawing on neo-institutionalism, which holds that symbols are 'instruments of interpretive order' (March and Olsen 1983, p. 741).

\section{Overview of papers selected for review}

We have adopted an 'intelligent' rather than a systematic approach to searching the literature. While it may be argued that a systematic review adds support for the genesis of a concept, we agree with Maclure (2005, p. 394) that 'systematic review systematically degrades the central acts of reviewing: namely, reading and writing, and the unreliable intellectual acts that these support, such as interpretation, argument and analysis'. Starting with a few key terms devised independently, the first two authors searched 'Google Scholar' and key journals in the field, the overarching criterion being that papers must have included empirical data gathered by means of observation of boards in session. We expanded our search terms as we read, incorporating what emerged as key ideas, and followed the threads where they took us. Finally, we compared our lists, noting overlaps and divergence. Though we think it unlikely, we cannot exclude the possibility that some papers that would have made the cut have been missed, for which we apologise in 
advance. The majority of the papers considered for inclusion have been published in peer-reviewed journals, but we also looked at conference papers and book chapters. Most of the research reported has been carried out since 2000, but we also looked at earlier research that we considered to have made a significant contribution. We have been selective in what we present below. In particular, we have rigorously excluded papers in which the analysis and discussion does not appear to have been informed by the observational data claimed to have been gathered.

While all the research referred to draws on direct observation of board meetings, these data range from field notes alone to audio, and, in a few cases, video data. All studies have also analysed other data, typically documents and interviews. A number of methodological approaches is evident, with most studies described as case studies or longitudinal case studies. Some have drawn on a mixed methods approach, though the majority are entirely qualitative. Most are of not-for-profit organisations, perhaps indicative of difficulties of access and a heightened sensitivity to this kind of research among for-profit companies. Among not-for-profits a range of settings have been studied, including the UK National Health Service (NHS), schools and colleges of further education, service/welfare organisations, sports bodies, and professional associations. Studies have mainly been conducted by outside researchers involving non-participant observation, though a small number of 'insider' studies are also reported.

Many of the journal articles reporting on direct observation of boards refer to the scarcity of this form of data and appeal to the need to 'open the black box' of governing (Huse and Zattoni 2008; Leblanc and Schwartz 2007; Machold and Farquhar 2013; Michaud 2014; Parker 2007, 2008; Pugliese et al. 2015b; and see also Huse 2005 and Roberts et al. 2005). However, little consideration is given to the ontological assumptions which attend 'opening the black box'. Indeed, it is a term that obscures as much as it reveals, reinforcing a positivist ideology of observation in which consideration of the ethics of representation or a reflexive consideration of what is ignored or not disclosed, is rarely encountered. Similarly, many papers refer to their work as 'processual', though the underlying ontological demands attending 'process' and the implications for understanding governing are rarely addressed.

Table 1 sets out the papers selected for inclusion in this review. The findings are presented below in relation to the three themes outlined above: empirical support for theories of governing; 'good' and 'effective' governing; and what is understood by 'processual' research.

\section{What support does observational research lend to theory?}

In the 'real' world of the governing board, support for theory is both limited and qualified. 'Pure' agency or stewardship relationships are rarely encountered. Most observational studies indicate a tendency towards passivity. Typical is Peck's (1995) study of 'board performance' in a NHS Trust in the UK. The study was conducted over a period of 18 months during which time 15 meetings were observed. Peck's findings indicate that most time was spent in the dissemination of information to NEDs and in approving proposals, leading Peck to conclude that the board 


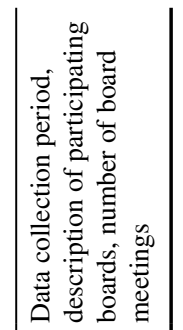

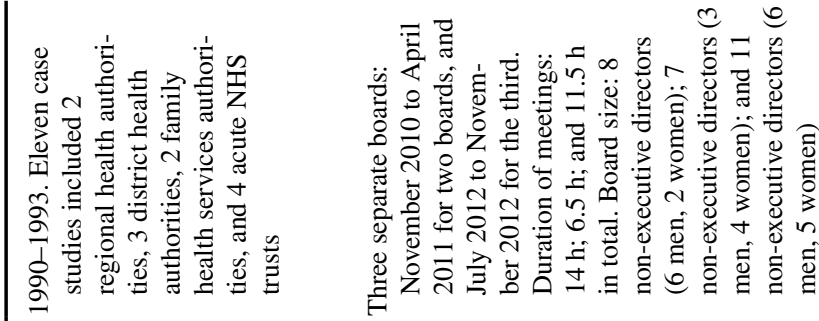

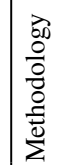

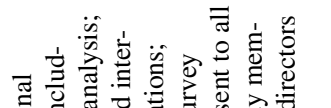

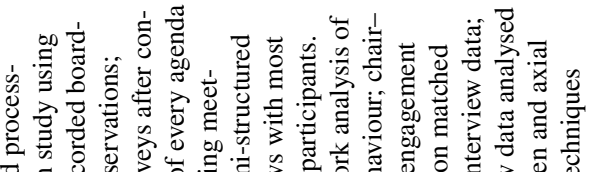

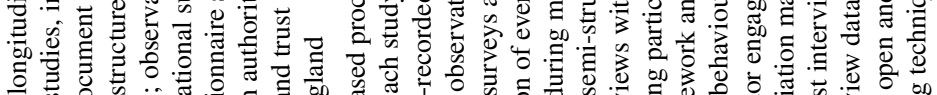

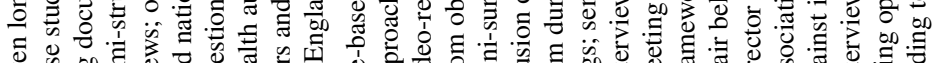

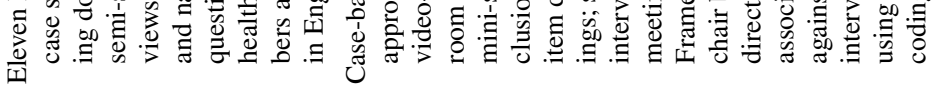

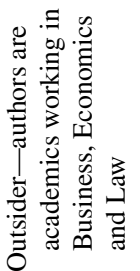

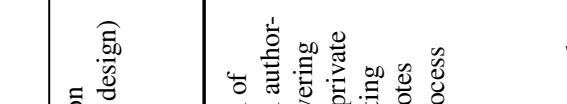

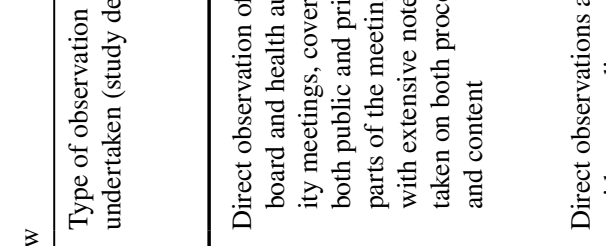

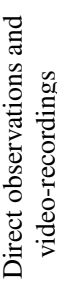

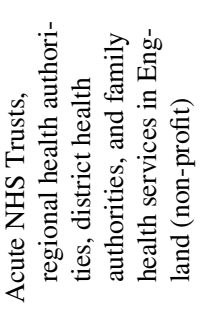

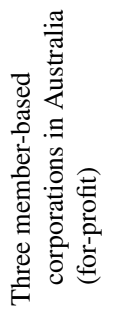

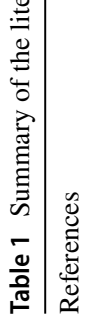

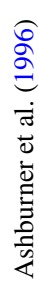

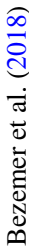




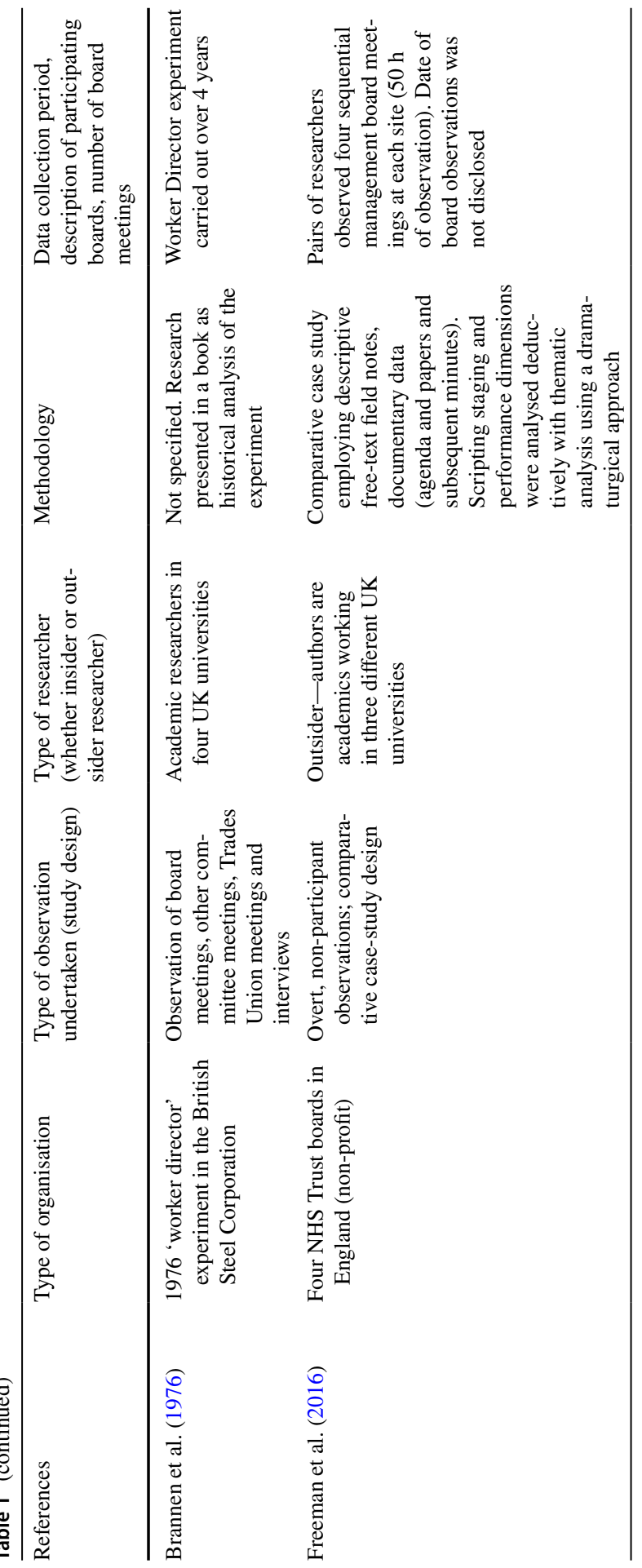




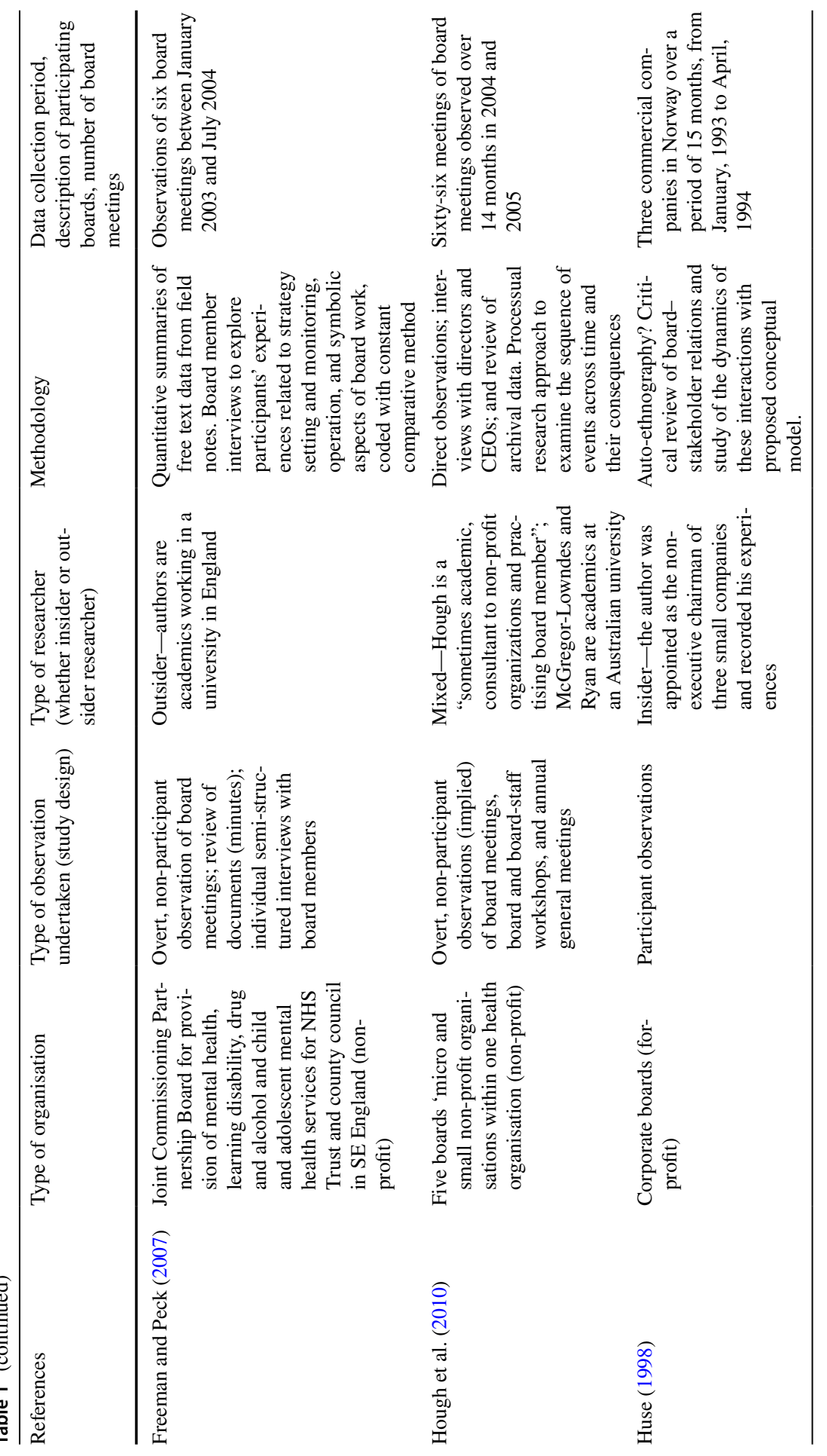




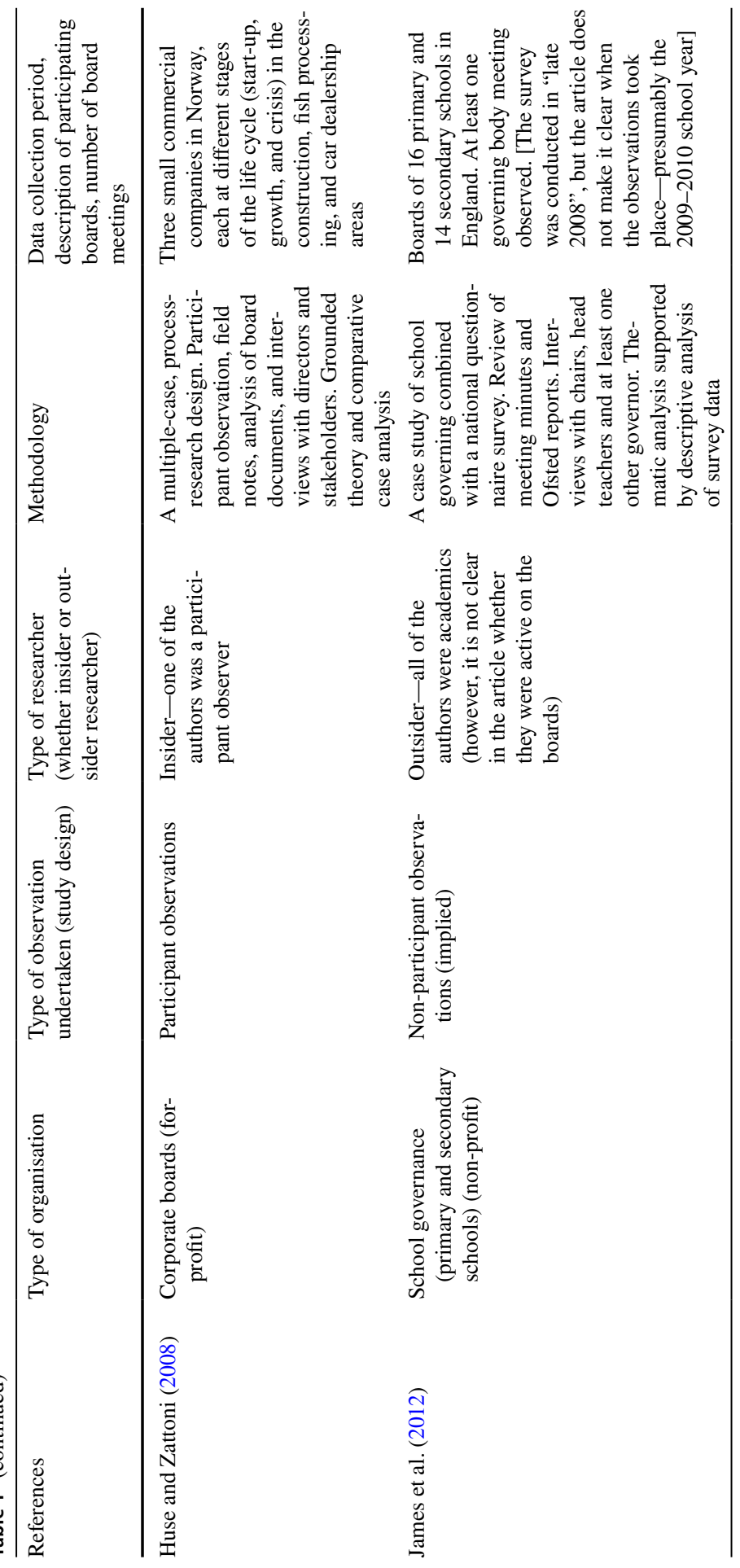




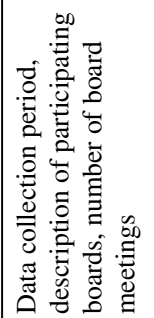

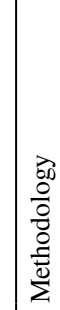

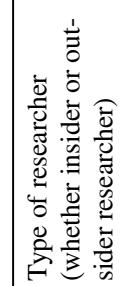

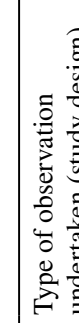

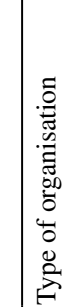

吾)

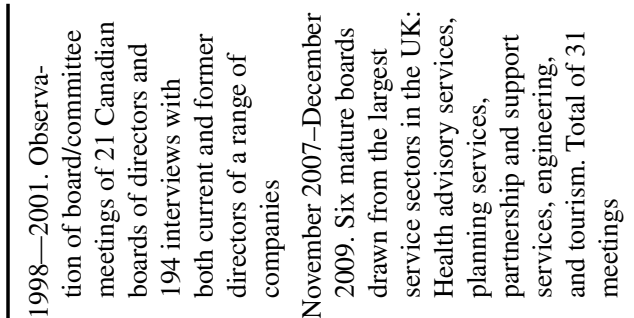

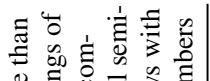

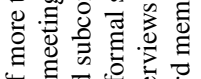

낭

的

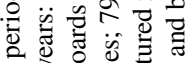

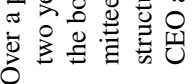

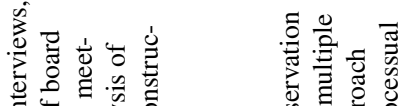

응 产

可言实占

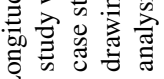

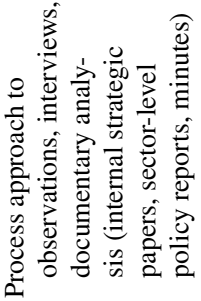

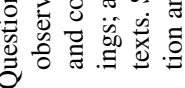

$\frac{\frac{v}{0}}{0}$

它

छ

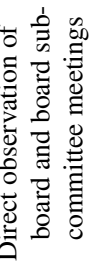

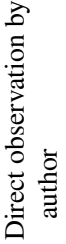

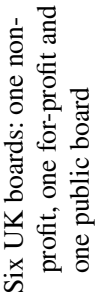

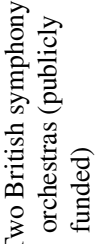

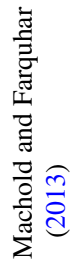

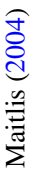




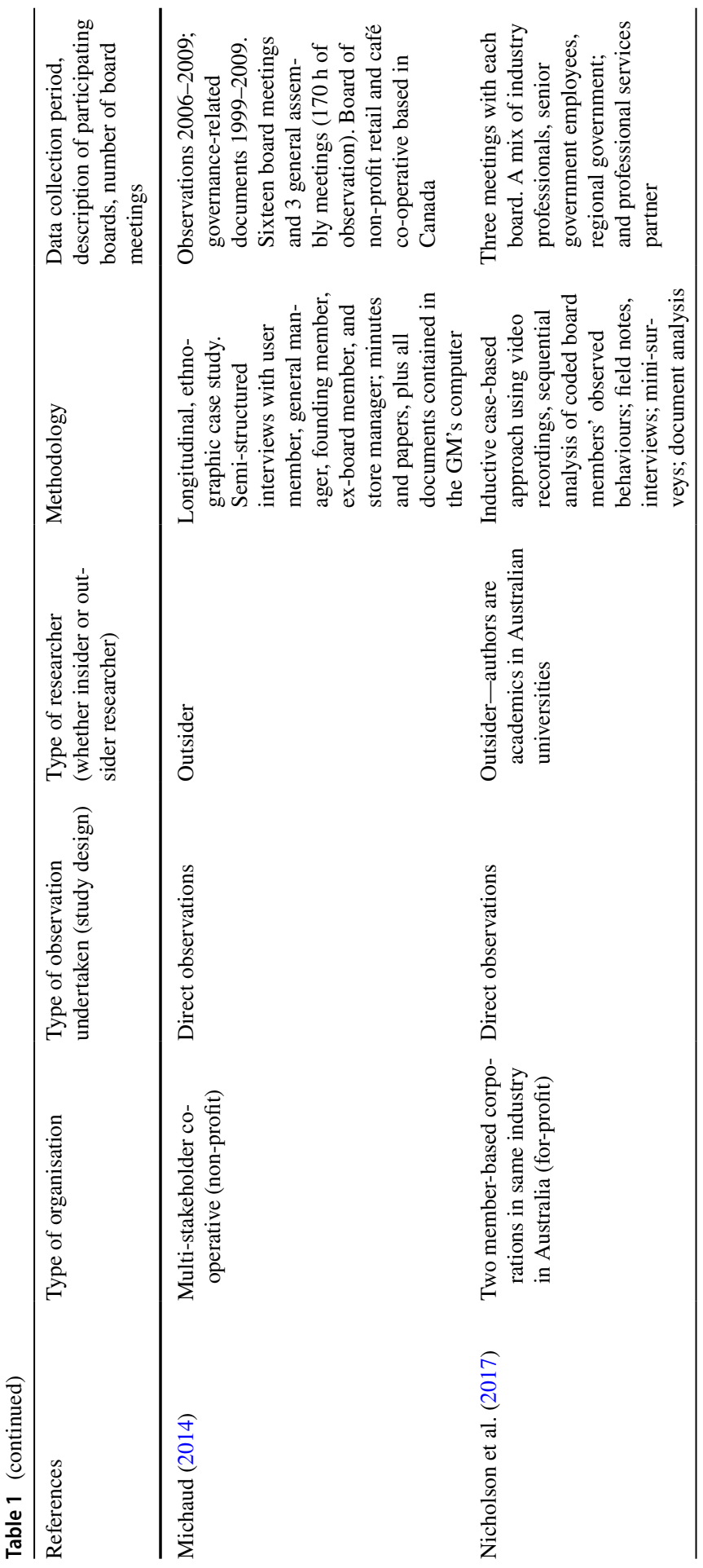



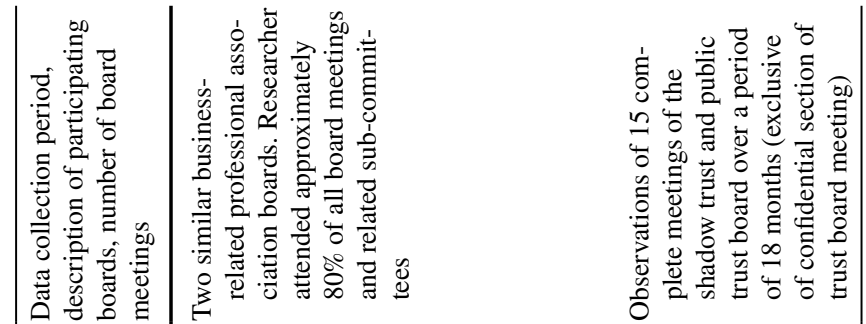

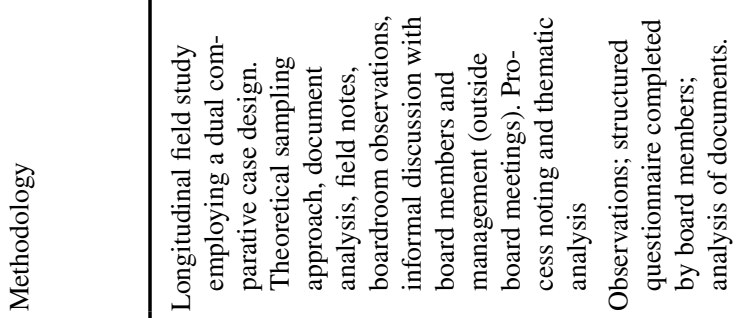

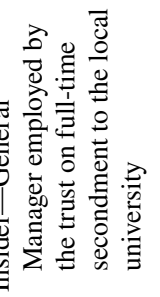

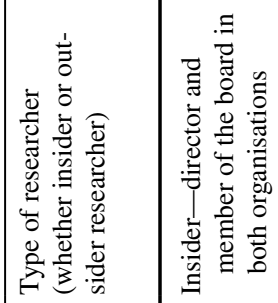

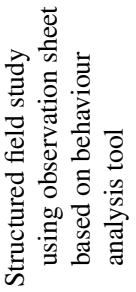

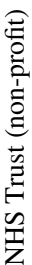

ลू
$\frac{y}{2}$
2 


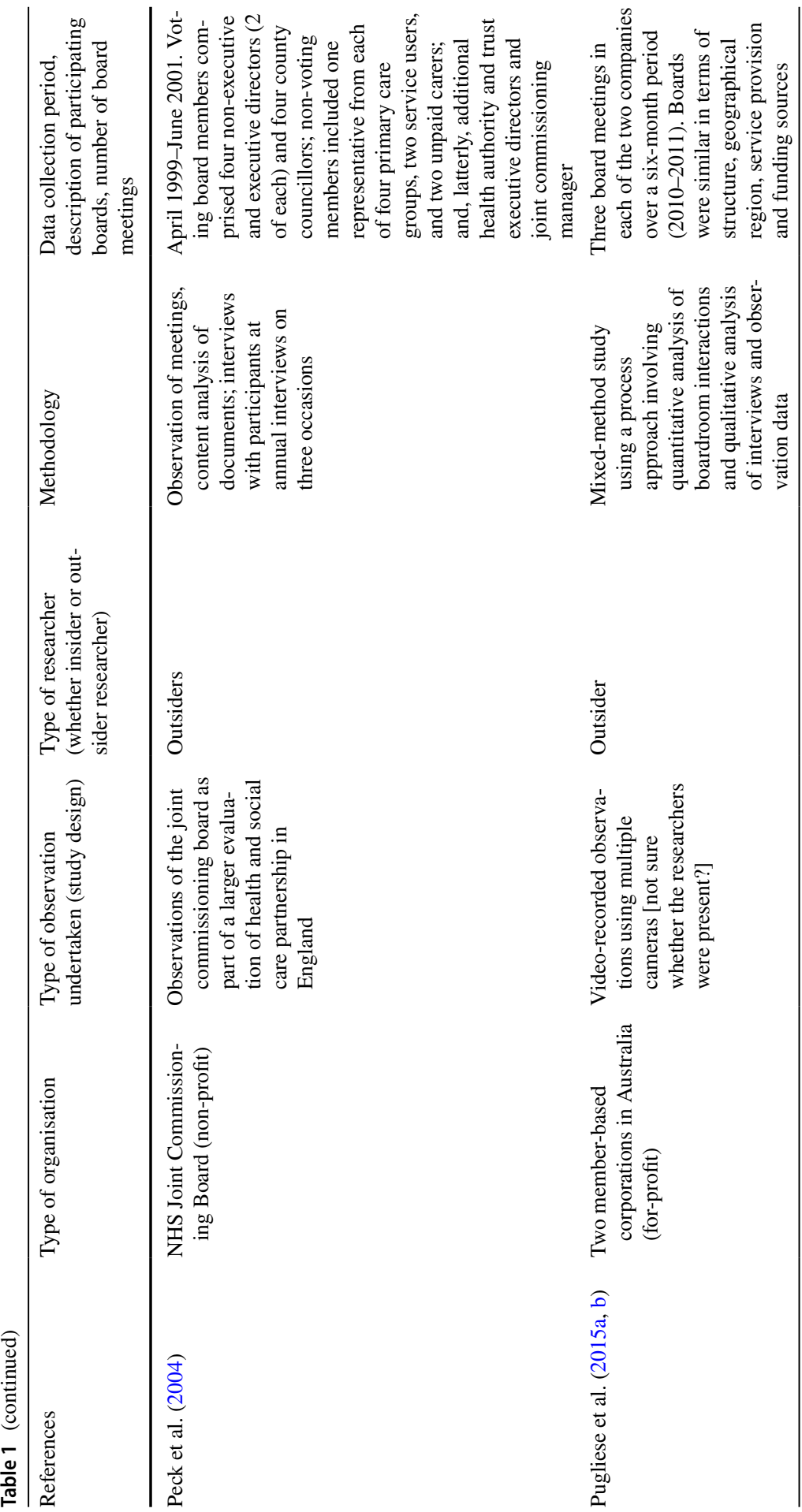




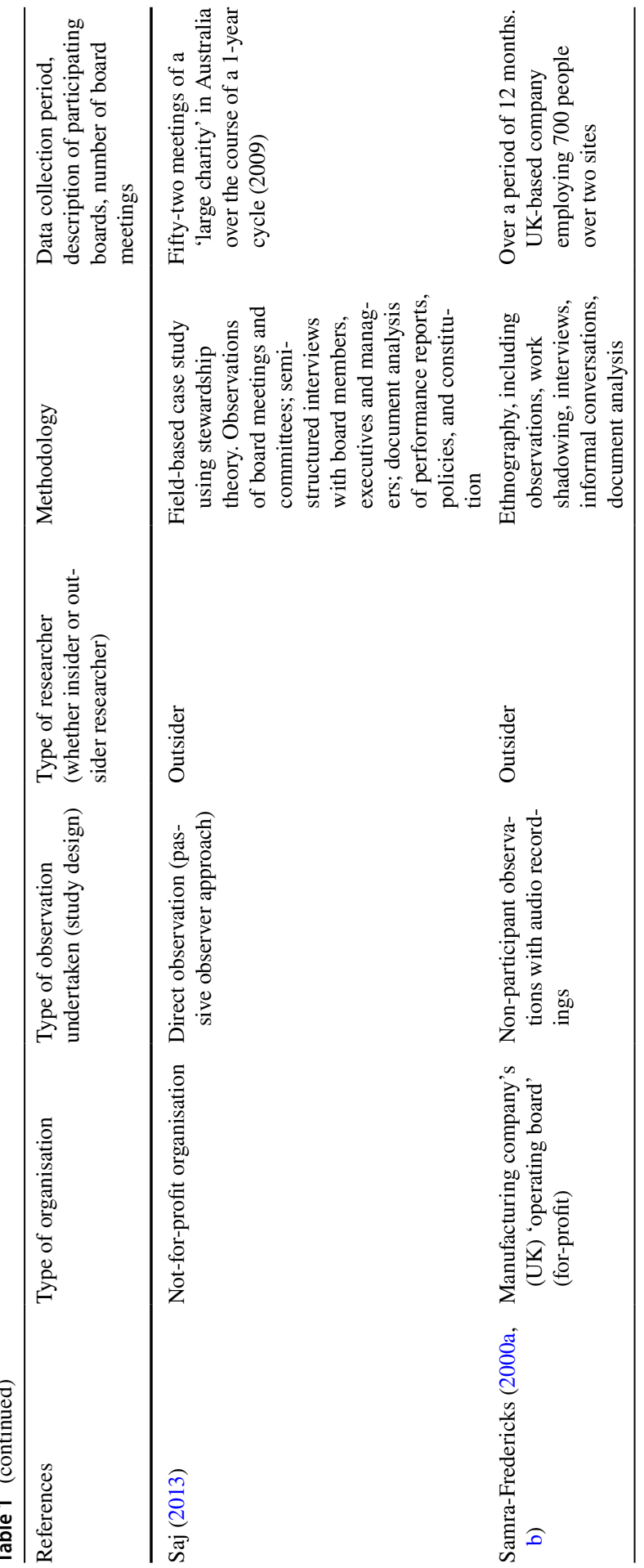




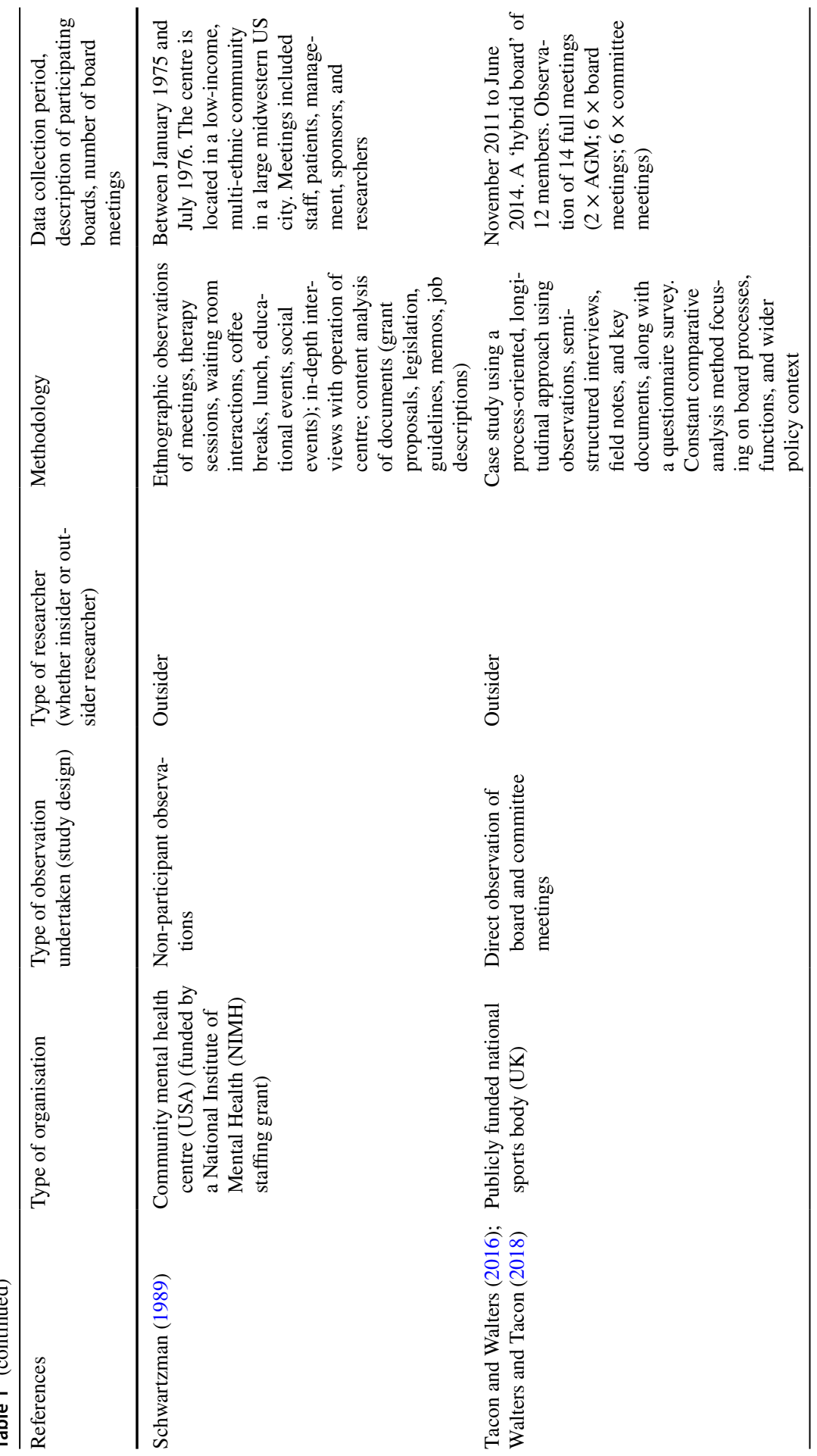




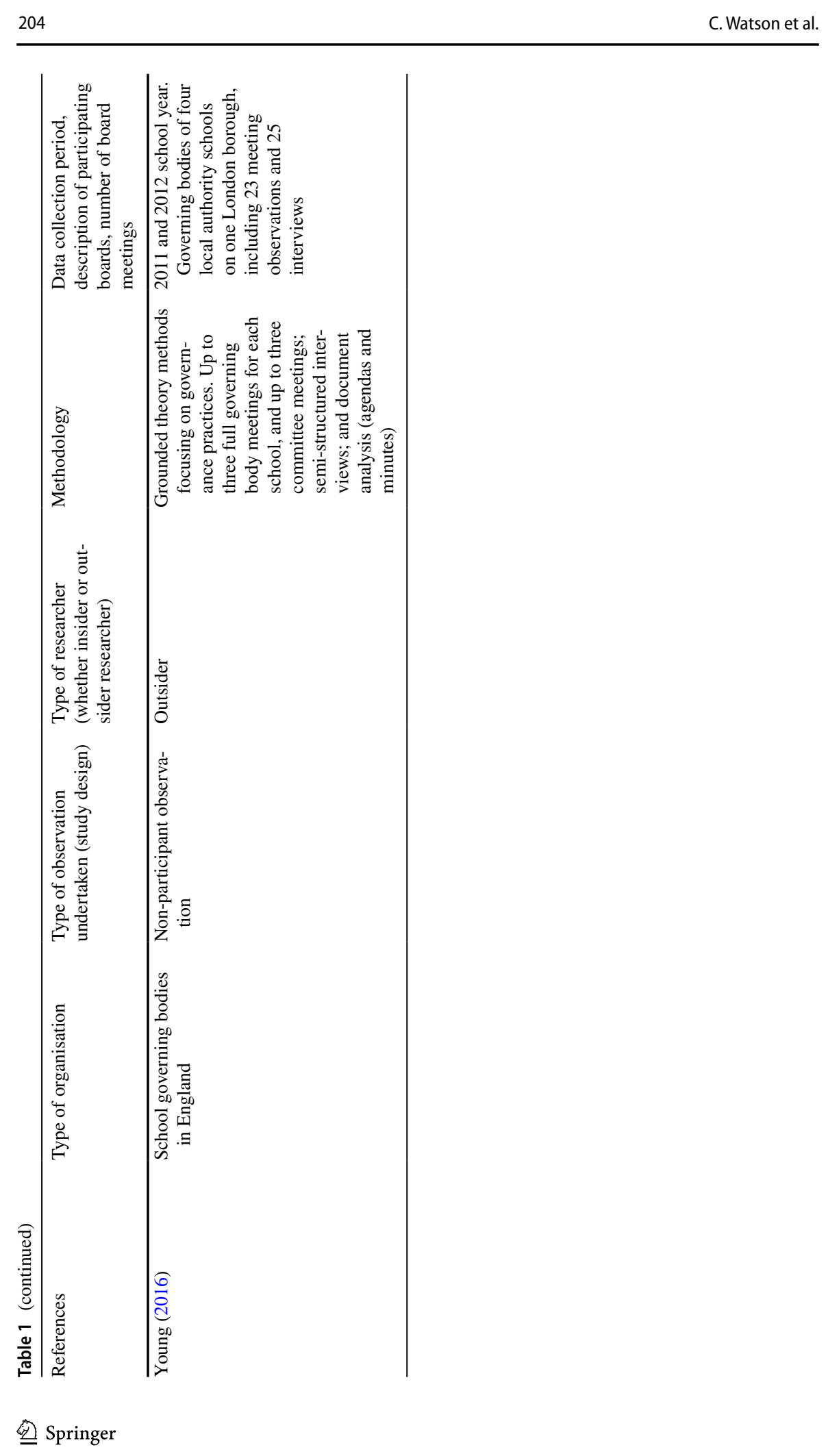


was 'primarily passive' and not engaged in strategy formation. Board behaviour thus contradicted prescriptive norms for corporate boards but is consistent with managerial hegemony theory. However, Peck notes too that though little time was taken up with challenges to executive directors the impact of this was greater than the time they took up (around 5\%) might suggest (Peck 1995, p. 153). Similarly, Parker $(2007,2008)$ served on the boards of two Australian not-for-profit organisations (both large professional associations) for a year before embarking on the research as a 'complete member researcher' over a period of 2 years. Parker notes a tendency towards 'passive acceptance of board committee recommendations' or 'mild questioning' (Parker 2007, p. 929). In a longitudinal study of the distribution of board tasks in six organisations (four not-for-profit, one for-profit and one public), Machold and Farquhar (2013) note that 'routine monitoring' and 'passive information dissemination' were the predominant activities - and this was particularly evident in the for-profit and public companies. However, they also noted that boards spent a great deal of time engaged in activities 'incongruent with current conceptualisations of board tasks' (p. 161), which mainly concerned information dissemination around operational issues. Taken together, the findings from these studies do not support the normative assumptions underpinning prevalent theories.

The passive/active binary may not, however, be very illuminating and reinforces the assumption that passive $=$ bad while active = good. Hendry et al. (2010) propose instead that board tasks should be conceptualised as 'procedural' (boards monitor and ratify decisions) or 'interactive' (the board is involved in strategy formation). According to this typology, board activity is conceived as a continuum from: receiving information, through scrutiny/challenge, to active involvement in strategy development - all of which are, to varying degrees and at different times, legitimate activities. This is demonstrated in Freeman and Peck's (2007) study of a NHS Board charged with developing strategy around commissioning and provision of health care services. Overall, the authors determined that, in relation to agenda items concerned with strategy, the board spent around a quarter of its time in challenge/amend mode, consistent with an 'active scrutiny' role. Similarly, in an earlier observational study of 11 NHS Trust boards undertaken at the time of their inception, Ashburner et al. (1996) noted that though these boards engaged in challenge and scrutiny they were not involved in the formulation of strategy. There was one exception, however. Over the course of a year, one board, established de novo, moved from receiving information, through scrutiny/challenge to being fully engaged in strategy development as NEDs grew in expertise and managers' confidence in them developed (Ashburner et al. 1996). In this case, the initial task for the board was, as Watson and Drew (2017) put it to 'constitute itself to and for itself', i.e., to define its role and develop membership ties. Only once this was achieved were they able to move towards strategy development.

The importance of context was also demonstrated in Huse's (1998) study of three commercial companies in Norway (see also Huse and Zattoni 2008). These cases were selected as they represented companies in very different situations: recovery from bankruptcy ('Recovery'); undergoing restructuring ('Reorganising'); and in need of re-financing ('Refinancing'). Huse, an academic, was appointed 'in the normal way' as the Chair to these three companies and 
maintained a journal over a 15 -month period as a participant observer. He concluded that the key function of the board varied: for Recovery the main role was creating legitimacy (one of the very few studies which relates to resource dependency theory); for Refinancing it was active monitoring of the actions of the manager (agency theory); and in Reorganising the board had a supportive or advisory role (consistent with stewardship). Huse and Zattoni (2008) analyse the findings of this study in relation to trust and its importance in empowering boards, which varied according to the stage in the board 'life cycle', and the composition of board's internal/external actors. Thus, a key consideration in assessing board performance is the nature of the dynamic relations which give rise to board learning.

The evolutionary nature of boards also featured in Brannen et al.'s (1976) seminal study of the 'worker director' experiment in the British Steel Corporation in the 1970s in which workers were appointed to the board. Though they provide frustratingly little detail in their report of this research, the authors note that the contribution of the worker directors changed over time. Initially restricting their input to areas of their own experience, as they developed confidence the worker directors 'were prepared to a greater or lesser extent to talk about almost all items which came to the board' (p. 182). Moreover, Brannen et al. observe that, since the worker directors were less knowledgeable about items brought to the board than many of the other directors, they had perforce to seek information through questioning. This provides support for Brennan et al.'s (2016) hypothesis that contra agency theory, information asymmetry is necessary to the control function of boards since this is what produces challenge.

While offering some important insights, the studies cited above are not based on video/audio data that could support a more fine-grained analysis of board interactional dynamics. One of the few studies which has taken cameras into the board room has been undertaken by a team of researchers in Australia. Pugliese et al. (2015a, b) and Nicholson et al. (2017) observed board meetings of two notfor-profit companies, collecting video data over a 6-month period. This involved observation of three meetings of each company analysed adopting a mixed methods approach including, unusually, a quantitative data set used to establish relationships between variables explored in more depth through the qualitative data. Pugliese et al. (2015a, b) examined the 'inner dynamics' of board meetings hypothesising a relationship between: time spent discussing agenda items, 'director dominance', and 'discussion quality' (as rated by board members immediately after completion of each agenda item). The research showed that greater interaction and evenness of participation were associated with more strategic and less operational boards; such meetings were characterised by greater challenge to management and the emergence of new ideas. Conversely, where insufficient time was accorded to agenda items, and where there was imbalance in participation, meetings tended to become 'information sessions' to which NEDs were less able to contribute. However interaction, as measured by turn-taking, duration of turns, and director participation/silence, not only varied between the two boards observed but within boards across agenda items, indicating the complex dynamics of board meetings which challenges the rather simplistic assumptions of theory. 
A study which goes beyond the positivist ideas underpinning much observational research is provided by Maitlis (2004). Maitlis examined the assumption that managers use information asymmetry to further their own interests at the expense of principals through an exploration of the boards of two UK symphony orchestras conducted over 2 years. Though Maitlis did not audio record meetings, she took field notes 'that were as near as possible to a literal transcript' (p. 1281). Instances of CEO influencing behaviours were analysed and from this four 'key influence processes' were defined: exploiting key relationships; managing impressions; managing information; and protecting formal authority. These influence processes are interconnected and 'temporally and contextually embedded', i.e., they build cumulatively over time. Maitlis' work challenges the assumption that the withholding of information inevitably leads to the board becoming a 'passive management tool', rather, it is the way that information is managed and with whom it is shared that is critical in building influence,

Influential CEOs are not those who never share what they know (for this could leave board members feeling uncomfortably ill-informed), but rather share just enough and at just the right times that they maintain their unique position in the information network. (Maitlis 2004, p. 1299)

Thus, Maitlis critiques the simplistic view of 'information' as a commodity to be withheld or exchanged, rather, information is a complex dynamic negotiated by members. Maitlis' work also supports Brennan et al.'s (2016) contention that information asymmetry concerns not only what is shared/withheld but also its quality. Managers' knowledge is often 'dirty' and ambiguous, based on direct experience, whereas board knowledge is founded on largely formal and second hand information. Moreover, asymmetry may also exist in relation to expertise and understanding of information presented to the board, which has clear implications for board development and recruitment.

\subsection{The 'control-collaboration paradox'}

Following Sundaramurthy and Lewis (2003) a number of studies have examined agency and stewardship and the 'control-collaboration paradox' that arises in the contest between them. Nicholson et al. (2017) examine the claim that governance failure arises from NEDs' inability to hold executives to account. The analysis adopted an inductive approach in which boardroom behaviours were identified and coded as supportive or accountability behaviours, and from which a model of boardroom accountability routines was developed. The findings of the research challenge the presumed patterns of accountability in 'traditional' agency theory, whereby managers provide an account of activities to the board, are questioned by NEDs, and then respond. Instead, the researchers uncovered a pattern in which accountability was distributed across the board. Insider/outsider status became blurred as NEDs took up and laid down particular roles, for example, being delegated responsibility for specific tasks such as committee work. This blurring of accountabilities was also found by Saj (2013) in a case study including observation of the board of a 
'large charity' in Australia, conducted over a complete annual cycle, examining how governance is 'co-produced' by board members and executives. Saj found considerable overlap in roles between board and management, leading to a relationship of interdependency consistent with stewardship theory. Parker (2007) also notes that the insider/outsider status of board members was on occasion blurred, as NEDs led discussions around areas of expertise or committee responsibilities, a finding that problematises the rather simplistic assumptions underpinning agency theory.

Smith and Lewis (2011) suggest that boards manage the control-collaboration paradox in a number of ways. They may separate the poles of the paradox either temporally or spatially, or they may embrace the ambiguity. The work cited above indicates that boards are able to manage, and even exploit, the paradoxical elements through complex processes of spatial/temporal separation; indeed, this may be a commonplace. Michaud (2014) investigated these relationships in a socio-material study of a not-for-profit cooperative in Canada over a 10-year period. In doing this she explored the role of numbers and other 'calculable spaces' as mediating objects, that is, objects that enter into and structure interactions within a group, especially as carriers of 'controversy, compromise or prescription'. Numbers occupy a privileged place in the work of governing boards, drawn on both to structure interaction and exercise control. Michaud demonstrated that, over time, and at different stages in the organisation's evolution, numbers were drawn on to mediate the paradoxical relation between control and collaboration in different ways. Michaud divides her observation period into five phases: from a developmental phase with numbers associated with aspirations and goal-setting in the co-operative (collaboration); through phases 2 and 3 characterised by a growing crisis around the performance of the manager in which numbers were used to hold to account (control); to a period of repair in which numbers were drawn on to 'reassure and pacify'; and a final period characterised by a 'control-collaboration duality' in which manager and board mobilised numbers in different ways to justify actions and challenge respectively. Michaud concludes that numbers 'modulated the distance between board and management [allowing] for the control-collaboration paradox of governance to be embraced' (Michaud 2014, p. 97).

\subsection{The role of the symbolic}

While the strategy role is assumed by analysts and members alike to be a key function of the governing board, a small number of studies have disputed the primacy of this, instead drawing attention to the symbolic role. Hough et al. (2010) observed five boards of 'micro and small not-for-profit organisations' operating in the health sector in Australia over a period of 12-14 months. Hough et al. extend Hendry et al.'s (2010) typology of strategising as procedural or interactive, adding a third category which they refer to as symbolic. In this scenario, the board engages in planning and produces a strategy, but it is the process of planning that is key, whether or not the plan is subsequently implemented. Strategising is thus a practice drawn on by the board by means of which it constitutes itself as a board. 
Work by Freeman, Peck et al. (2004; Freeman and Peck 2007) also considers the symbolic nature of governance. They undertook observation of a NHS Board charged with developing strategy around commissioning and provision of health care services. Peck et al. (2004, pp. 105-106) argue that ritual performed a number of functions: 'sustaining social solidarity between elites'; as a 'method of institutionalising codes of speech'; creating consistent patterns of response; and overall as creating 'organisational settlement', i.e., in constituting the organisation as the kind it was. However, there was interplay between the symbolic and the instrumental aspects. Freeman and Peck (2007) concluded 'in the midst of the instrumental there is theatre and the performance may yield instrumental results - indeed, the symbolic may provide the means and language by which instrumental work is enacted' (p. 923). As March and Olsen (1983, p. 742) observe, 'rituals seek to establish ... not only the virtue of events but also their necessity.' These findings are relevant to neo-institutionalist theory which challenges the priority of instrumentalism over symbolism.

Schwartzman (1989) too questions the 'cultural premise' that the purpose of board meetings is to engage in strategic decision-making. Like March and Olsen (1975), she regards decision-making as 'a post-factum construct'. Schwartzman undertook an ethnographic study of a health centre in the US, tracing events surrounding the appointment of a new director following a period of turbulence concerning the outgoing director. There were two candidates for the post: one internal, the other external. Schwartzman observed the board meeting at which the new appointment was made. Although participants at the meeting in retrospect spoke of this decision as a foregone conclusion, this was not apparent from Schwartzman's field notes as the meeting unfolded. In fact, the successful (internal) candidate was not widely popular and was not supported by all board members. However, this candidate was known to the board while the other had nothing but himself to recommend him,

Talking about [the outsider candidate] invoked abstract concepts (leadership skills, ideals about staff delegation of authority), but although these might produce a discussion about an ideal person or an ideal organization, they could never produce 'the organization'. (Schwartzman 1989, p. 238)

Schwartzman argues that the situation concerning the outgoing director caused an existential crisis over several months during which time the identity of the board had become fractured. Discussion around the internal candidate enabled the board to reconstitute itself in relation to the organisation, while the other candidate did not. In a neat ironic reversal, Schwartzman concludes that, rather than the purpose of meetings being to make decisions, the opposite is true-'decisions make meetings, and meetings make, remake, and sometimes unmake the organization’ (p. 239).

\section{6 'Good' versus 'effective' governing}

While theoretical models attempt to provide explanations which account for governing, one of the reasons for carrying out research on governing is to establish what is 'effective' (however defined). A related question concerns the extent to which 
'good' governance, as conceived in a range of prescriptive codes, is informed by this research and hence the relationship between good and effective governing.

\subsection{Good governance}

In recent years, codes of governance have become ubiquitous in both for- and nonprofit organisations, with global convergence evident (Jørgensen and Sørensen 2012). Most have some legal force and adopt a policy of 'comply or explain' (e.g., Australian Securities and Investments Commission, nd; Financial Reporting Council (FRC) 2018; Association of Colleges 2015; Sport England nd). An exception is the UK charity governance code (Charity Governance Code Steering Group, nd) which is not legally binding and adopts the principle 'apply or explain'. Although codes may differ in detail, they generally comprise: the role of the board, its responsibilities and legal duties; board procedures; accountability (including the need for various committees, principally around audit and remuneration); and board evaluation. As noted earlier, codes also set out the board's corporate and social responsibilities. In addition, many of the codes covering not-for-profit organisations in the UK refer explicitly to the Nolan Principles of public life, which apply to all 'public office holders' (selflessness, integrity, objectivity, accountability, openness, honesty, and leadership) (Gov.uk, nd). It follows from this that 'good' governance may be defined as forms of governing which comply with the letter and spirit of their respective code.

Understandably perhaps, codes of governance conflate good and effective governance. This is challenged, however, by research findings which demonstrate divergence and a tendency towards the emergence of unanticipated consequences (Merton 1936). Tacon and Walters (2016) observed the governing board of a UK-based national sports body funded by Sport England over a period of 1 year. Observations revealed that the board explicitly oriented to its code of governance, 'at times, board members directly invoked ... the text of particular governance guides, when constructing and enacting their board roles' (p. 376). In particular, they adopted a 'professional logic' which understood the role of the board in strategic decision-making within an overall discourse of 'modernisation'. However, although there was much 'governance talk', around which a clear consensus emerged, there was little evidence that this led to more effective practices. In fact, the authors point to an 'ongoing conflict' which circulated around the fundamental question of the board's representative role, i.e., the constitution of the board in relation to its stakeholders. Walters and Tacon (2018) conclude that the code constrained the autonomy of the board, preventing them from taking measures that they believed would enhance organisational effectiveness.

Similarly, Young (2016), in a study of four school governing boards, observed how governors enacted 'prescribed criticality' through guidance provided by Ofsted (UK Office for Standards in Education) on the 'right' kinds of questions to ask. This, Young argues, gave rise to a 'neoliberal rationality of effectiveness' (p. 172) and she concludes, 'Governors are encouraged to keep busy asking prescribed questions, but are passive in considering what conception of "good" education lies behind these 
questions' (p. 173). In this way, in an ironic reversal passivity is enacted as participation. While this might be 'good' governance, its relationship to effectiveness is less clear.

This was also the conclusion reached by Freeman et al. (2016) in their investigation of governing practices in four NHS Foundation Trust boards in England. The study focused on strategic developments in relation to infection control data and patient safety. The authors undertook a comparative case study across four representative sites (Freeman et al. 2016). Four board meetings were observed in each location. Adopting a Goffmanesque dramaturgical approach, Freeman et al. examined the work of the board along four dimensions: scripting (how participants are positioned through the activity); setting (physical environment and artefacts employed); staging (how interaction is deliberately organised by participants); and performance (how contextualised interactions construct the social realities at hand). Unlike coding, this analysis preserves the integrity of the data. A range of patterns of activity was identified, each encompassing different practices, which were stable over the period of observation. These practices used infection control data to construct social realities in different ways. At only one site did practices of governing align the use of this data with 'improvement processes' to develop strategy aimed at driving performance around infection control. At the other three sites, governing practices produced different social realities, including: apportioning blame; the reclassification of targets under a risk management traffic lights system from 'amber' (requiring external scrutiny) to green (no external involvement necessary); and dismissal of targets as 'unrealistic'. Crucially, while the work of all boards was held to accord with 'international norms', the extent to which these led to improvement was questionable. The authors concluded that 'governance activities remain contingent on board dynamics' (p. 247).

\subsection{Effective governance}

Effectiveness in codes of governance is defined in relation to the tasks demanded of the board and the responsibilities of key participants in this. Guidance on board effectiveness (FRC 2018), for example, explicitly recognises the importance of procedural, cultural and inter/personal factors underpinning effectiveness. The chair is held to play a particularly important role including facilitating the meeting, fostering relationships, enabling open communication, and setting the boardroom culture, consequently, a good deal of board effectiveness research focuses on the chair and chair behaviour.

Leblanc (2003) studied boards of 39 companies over 5 years, including attendance at board/committee meetings at 21 of these sites (Leblanc 2003, p. 78). His work highlights the importance of board member behaviour in relation to key tasks from which he developed a typology of 'effective' and 'dysfunctional' boards based on 10 'director types', conveniently all starting with the letter $\mathrm{C}$. The five effective types were: Change Agents, Consensus-Builders, Counsellors, Challengers and Conductors; and the five dysfunctional types: Controllers, Conformists, Cheerleaders, Critics and Caretakers. Leblanc concluded that board process and the 'behavioural characteristics of individual 
directors' was crucial, certainly more important than board structure or director competence. Within his typology the role of the chair was held to be pivotal. Leblanc characterised effective boards as being chaired by 'Conductors' (work towards consensus, manage dissent, act as a 'hub') and dysfunctional boards by 'Caretakers' ('under-controlling', lacking leadership).

Bezemer et al. (2018), also who examined the role of the chair in a study of three not-for-profit boards described as 'member-based corporations'. Analysis produced three main chair 'behaviours': giving personal views; facilitating; and providing information. In all three boards, facilitating was the main activity, and providing information the least. Across the boards, wide variation was seen in the amount of time the chair spent talking and this was negatively correlated with director satisfaction with chair performance. Overall, NED engagement was lower when the chair was highly involved. The authors concluded that 'a heavily involved chair undermines the agency of the other directors' (p. 226). This is also noted by Pugliese et al. (2015a), who write, 'A board that requires a chair to actively participate may be exhibiting signs of dysfunction rather than effective chairing' (p. 37). This was particularly evident in one of the boards investigated, 'where the chair was undertaking textbook facilitation behaviours (focusing discussion, keeping the meeting moving and so on) that were viewed by the directors as inhibiting the discussion and effective task execution' (p. 37). A similar concern was noted by James et al. (2012) in their study of school boards.

Parker's $(2007,2008)$ participant observation of the boards of two Australian notfor-profit organisations also examined facilitation of meetings by the chair. In both boards he observed an informal style which 'appears to enable both transparency of exchanges and critique, defuse confrontation and stress, and simultaneously maintain cohesion among directors even at points of intense debate or disagreement' (p. 932). However, while acknowledging the use of informality and humour to facilitate director engagement in meetings, he also noted that these '[sometimes] appeared to restrain directors from aggressively pursuing or critiquing issues' (p. 929). This, points to a tension between fostering relationship and ensuring open communication not acknowledged in normative codes. These findings indicate the potential of empirical research to add to knowledge around the contradictions and tensions of the work of boards and to illuminate the ways in which codes of governance serve as disciplinary mechanisms which serve to interpellate boards into dominant discourses.

However, despite attempts by codes of governance to render synonymous good and effective governing, there is an obvious temporal disjunct between them. Outcomes of board meetings may be related to the management and orchestration of board dynamics by the chair, but effective governing (unlike good governing), is another 'post-factum construct' (March and Olsen 1975), narratively assembled after the event.

\section{Observational research and claims to process}

Many of the papers examined in this review equate observation with a process approach (Parker 2007, 2008; Hough et al. 2010; Maitlis 2004; Pugliese et al. 2015a, b; Tacon and Walters 2016; Nicholson et al. 2017;Bezemer et al. 2018). However, as 
Jarzabkowski et al. (2017) point out, there is a weak and strong use of this term. In weak process research, the aim is 'to understand the temporal evolution of things or substances that nevertheless retain their own identity over time' (Langley and Tsoukas 2017, p. 3). Thus, processes are forces of change that push substances around, effectively giving primacy to substance over process (Rescher 1996). Strong process approaches, by contrast, draw on process metaphysics, which entails an 'ontological commitment that views the world as constantly becoming' (Langley and Tsoukas 2017, p. 4). Bergson (1913) set out the challenges of adopting such a commitment. For Bergson, experience is bound up with the continuous flow of time as durée. 'Conceptualising thought' is incapable of adequately grasping this flow and instead attempts to capture and stabilise it as things (including time itself). In other words, we have a tendency to reify as 'things' ongoing processes, abstracting these from the continuous flow of time. Adopting a commitment to a process ontology entails seeing organisation in a constant state of flux in which process produces substance. This requires a radically different approach to research and explains why a strong process approach to research on governing boards is much scarcer than its weaker variant. Indeed, of the research presented above which claim to be 'processual', the vast majority is 'weak' process research. Arguably, any research which employs coding to abstract and reduce data to identifiable categories can be said to fall into the weak category. Strong process approaches, by contrast, look for patterns of activity exhibiting repetition and difference (Deleuze 1994). Hence 'situated action' is a key feature of processual research (Jarzabkowski et al. 2017, p. 238).

Pettigrew (1997, p. 140) outlines a set of criteria by which process research may be judged. These relate to: embeddedness (the contexts which both produce and are produced by the social phenomenon under study); temporal interconnectedness (understanding the flow of events over time); attention to the ways in which context shapes actions; a search for holistic explanations; and having the 'ambition' to link process to outcomes, while recognising that this outcome is not an end point but is itself caught up in the ebb and flow of process.

This is an exacting list of requirements and, while probably none of the work cited in this paper can lay claim to all, some contain features of it. Freeman et al. (2016) and Michaud (2014), for example, certainly do (though interestingly neither lays claim to be being processual): Freeman et al. clearly maintain the holistic integrity of explanations within and between cases; Michaud attends to temporal interconnectedness and the ways in which actors both shape and are constrained within contexts. Of the research so far presented, however, Schwartzman's (1989) analysis perhaps comes closest to embracing a commitment to the ontology of process, showing how the organisation is immanent in the emergent and contingent processes of 'decision-making'.

Another example which deserves consideration is Samra-Fredericks' (2000a, b) study of governing in a UK manufacturing company. Samra-Fredericks video/audio recorded teams of directors and senior managers over a series of monthly meetings in order to uncover the 'tacit knowledge and skills deployed to influence boardroom process' (2000a, p. 246; original emphasis). In addition to observation of board meetings, a range of ethnographic data were also gathered which served to contextualise the analysis. In each of the papers, 
Samra-Fredericks presents a small fragment of data capturing the apparently mundane, but actually 'dazzling' linguistic competence displayed by participants as they enacted influence, leadership, authority, etc. Samra-Fredericks (2000a) focuses on the use of personal pronouns (I, we, our) and how these are used by members to draw on their own power bases and sources of authority to exercise influence. In 2000(b), she considers the use of 'well' and 'but' as conversational markers used to indicate areas of potential disagreement and extends the analysis to show how, at the micro-level of communicative exchange, negotiation is effected and influence enacted. Overall, Samra-Fredericks argues, the analysis builds up in layers to reveal 'aspects of real time strategic story-telling' (2000b, p. 323; original emphasis). Although Samra-Fredericks does not refer to her work as 'processual', it is clear from her analysis that the ontological commitment is to the immanence of strategic decision-making within the flow of interaction. Samra-Fredericks (2000b, pp. 323-324) concludes,

Whilst some may suggest that the 'Is' and 'wells' of talk take us into the realm of trivia, what we cannot disregard is that which we strategically and pragmatically $d o$ through deploying these basic linguistic resources. Indeed, only through such micro-analysis can we really understand and appreciate the eventual construction of the spectacular, that is board process and the setting of strategic direction and other 'outputs' as stated in the 'boards standards model.

Schwartzman and Samra-Fredericks undertake very different forms of analysis-Samra-Fredericks focusing on the minutiae of linguistic production and its sequential and layered production in real-time; Schwartzman adopting a traditional ethnographic approach, working from field notes and retrospective interviews. However, in both, time is made to count as the medium through which process is effected. In other words, it is clear from both that it is through process that the substance of the organisation is created.

\section{Discussion: an agenda for research}

While research has yielded some insightful accounts, the field is not well developed and arguably has not (yet) delivered on the promise to open the 'black box' of governing. As Machold and Farquhar (2013) eloquently put it, 'the lid of the black box has been lifted but there remain many dark corners'. With a few notable exceptions, most of the work in this area has been interpreted within an objectivist conception of the board, arguably influenced by the norms of governance organised around competing positivist theoretical conceptions, which fail to acknowledge the multiplicity of the phenomena being observed (Crow and Lockhart, 2015). Very little has been conducted within constructivist, let alone 'post' paradigmatic conceptualisations. In this final section we briefly suggest an agenda which builds on this existing body of work and takes the field forward. 


\subsection{Theories of governing}

Observational research does not offer unqualified support for any of the main theories of governing. Overall, research tends to confirm the view that most board meeting time is spent in receiving information and offering up mild challenge (Peck 1995; Peck et al. 2004; Parker 2007). However, taken together, the research offers a nuanced view of this and provides some insight into the conditions which promote an active role (Pugliese et al. 2015a, b). Moreover, research carried out over an extended period provides insights into the developmental nature of boards. In this regard, Brannen et al. (1976), Ashburner et al. (1996), Huse (1998) and Michaud (2014) all show how patterns of interaction may change over time, depending on context and the evolutionary stage of the board. Such findings point to the importance of attending to the relational dynamics and entanglements between actors in the governing process (Huse et al. 2005) and the need to attend to board learning, drawing on recent research around professional learning and practice (e.g. Fenwick et al. 2012; Nicolini 2016).

Surprisingly, the contest between agency and stewardship and the apparent paradox that surrounds control/collaboration does not emerge as a major issue for boards. Michaud (2014) found boards able to navigate control and collaboration through the use of numbers as mediating objects; while both Nicholson et al. (2017) and Saj (2013) found that accountabilities tend to be distributed across the board, suggesting that the 'paradox' is more theoretical than found in practice. This suggests that research around committees and how they support the work of the main board could add significantly to knowledge of board function.

The role of information asymmetry as a tool by which managers control boards is problematised by observational research which reveals it to be a more subtle and interactive process than agency theory assumes. As Maitlis (2004) shows, the view in agency theory of information as a commodity to be exchanged is simplistic. Rather, 'information' forms part of an elaborate repertoire, used subtly to bring about influence. Disjuncts between manager and board knowledge is an area that warrants further attention. Linguistic analyses, enabled by securing video access to boardrooms, would provide useful insights.

While a focus on strategy in organisational studies has flourished in recent years with the growth of the strategy-as-practice turn (Whittington 1996; Jarzabkowski 2004), very little of this has informed the research on governing boards. In particular, very few empirical studies examine how boards 'do' strategy, nor about how this aspect of the role is entangled with other key functions of the board and hence how this 'produces' organisation. In addition, little has been said about value added by boards in doing strategy. Indeed, Judge and Talaulicar (2017) raise the interesting question, whether boards may be too involved thereby undermining the authority of management. In sum, the passive/active binary opposing agency and stewardship has been unhelpful in obscuring the complexity of processes of strategising. Approaches which explore ways in which governance is communicatively constituted through the processes and practices of the governing board and associated activities would extend the field (Cooren et al. 2011) as would research which considers the materialities of embedded practices 
as constitutive of everyday organising (Fenwick 2016; Balogun et al. 2014; Jarzabkowski et al. 2015).

Finally, we may note that very little appears to be said about resource dependency theory in the literature. However, the ways in which expertise is drawn on in the boardroom, the reputational capital accruing from board membership, and the networks to which the board provides access, are clearly areas that warrant detailed examination.

\subsection{Good and effective governing}

While there is a tendency to conflate good and effective governance, these are clearly distinct: good governance may be defined as compliance with a normative code; effectiveness must be assessed in relation to the performance of the organisation (however defined), hence necessarily post hoc. The difference between the two was clearly evident in studies reported here. Walters and Tacon (2018) argue that explicit orientation to a code prevented the board from taking measures that would enhance organisational effectiveness; Young's (2016) research participants worked within a very prescriptive code, the effect of which was to deflect board members from a consideration of the wider aims and purposes of the organisation; while in Freeman et al.'s (2016) study compliance with international norms resulted in very different outcomes, only one of which might reasonably be expected to benefit patients. Similarly, Bezemer et al.'s (2018) study of board chairs produced findings that challenge received opinion regarding the actions of the chair in facilitating good governance, suggesting that 'text book' facilitation behaviours may inhibit active participation of board members. These findings point to the importance of irony as a means to gain insight into governance failure (Watson 2019).

If 'good' governance can be defined as compliance with a respective code, effective governance is more problematic-effective in relation to what? If the answer to this is the realisation of the organisation's aims, this still leaves unclear how this is to be done: is it through its instrumental actions-its scrutiny and challenge, its active role in shaping strategy? Or is it about the symbolic and the 'kind' of organisation constructed through enactments of governing? Research has very little to say about this. As Crow et al. (2016, p. 1026) assert, 'no explanations of how and why improved performance occurs as a result of active boards have been provided to date'.

\subsection{Processual methodology}

The third theme examined claims concerning the processual nature of research on governing boards. Here we find evidence of Jarzabkowski et al.'s (2017) divide between 'strong' and 'weak' approaches with different ontological commitments. While both offer insights of use to the field, both have limitations. Weak approaches collapse time: actions are abstracted and classified to produce events that are termed 'governing'. In 'weak' process research, the analyst adopts uncritically the members' reification of processes as 'things', thereby committing the 'fallacy of 
misplaced concreteness' (Whitehead 1929). The task for the researcher adopting a strong approach is to understand the processes by which this reification, as member perceived enactments of governing, occurs. However, there is the danger that strong approaches which focus on micro-level practices (decision-making, use of linguistic markers etc.) do not address the uniqueness of governing which make it different from other aspects of organisation. This suggests a need to develop approaches which focus on board level activities in order to capture governing as immanent.

\section{Conclusion}

In relation to theories of governing and principal-agent relationships, it is clear that these offer only partial explanations. None is able to offer an account which adequately recognises the complexity of the processes and practices involved. Arguably, the 'paradoxes' that have emerged (on paper) owe more to the differing paradigmatic frameworks of these theories than to any 'objective' reality. For this reason, sociological analyses are required which bring the lens of social theory to bear on governing as a complex social phenomenon. In particular, sociomaterial approaches would shed light on enactments and practices of governing and the assemblages and networks that constitute governing within the boardroom and beyond.

Approaches which look for 'good' and 'effective' governing are similarly challenged. Rarely are the assumptions which underpin these discursively orchestrated constructs examined. Rather, analysts tend to adopt uncritically members' constructions of these norms, hence a focus on 'core' activities such as strategy, support/ service, and control. There is therefore a need to better understand the contexts and constraints within which governing is enacted and the discourses within which 'good' and 'effective' governance are constructed.

Finally, while 'strong' process approaches may be more attuned to the emergence of governing, such approaches need to found their commitment to an ontology of process more robustly (Hodges 2008). Moreover, bringing process approaches to the study of boards has to be attuned to the level of the board as the unit of analysis in order to foreground the uniqueness of governing as that which constitutes the organisation.

Taken together, such approaches may yield a body of knowledge that addresses the question of how the board enables the organisation to realise its aims (if indeed it does).

Funding Funding was provided by Economic and Social Research Council (Grant No. ES/R00322X/1).

Open Access This article is licensed under a Creative Commons Attribution 4.0 International License, which permits use, sharing, adaptation, distribution and reproduction in any medium or format, as long as you give appropriate credit to the original author(s) and the source, provide a link to the Creative Commons licence, and indicate if changes were made. The images or other third party material in this article are included in the article's Creative Commons licence, unless indicated otherwise in a credit line to the material. If material is not included in the article's Creative Commons licence and your intended use is not permitted by statutory regulation or exceeds the permitted use, you will need to obtain permission 
directly from the copyright holder. To view a copy of this licence, visit http://creativecommons.org/licen ses/by/4.0/.

\section{References}

Ashburner, L., Ferlie, E., \& FitzGerald, L. (1996). Organizational transformation and top-down change: The case of the NHS. British Journal of Management, 7(1), 1-16.

Association of Colleges. (2015). Code of good governance for English colleges. Retrieved November 8, 2019, from https://www.aoc.co.uk/funding-and-corporate-services/governance/governance-resou rces/code-good-governance-english-colleges.

Australian Securities and Investments Commission. (no date). Corporate governance. Retrieved November 8, 2019, from https://asic.gov.au/.

Balogun, J., Jacobs, C., Jarzabkowski, P., Mantere, S., \& Vaara, E. (2014). Placing strategy discourse in context: Sociomateriality, sensemaking, and power. Journal of Management Studies, 51(2), $175-201$.

Bergson, H. (1913). Creative evolution. New York: MacMillan.

Berle, A. A., \& Means, G. C. (1932). The modern corporation and private property. New Brunswick: Transaction Publishers.

Bezemer, P., Nicholson, G., \& Pugliese, A. (2018). The influence of board chairs on director engagement: A case-based exploration of boardroom decision-making. Corporate Governance: An International Review, 26(3), 219-234.

Boyd, B. K., Haynes, K. T., \& Zona, F. (2011). Dimensions of CEO-board relations. Journal of Management Studies, 48(8), 1892-1923.

Brannen, P., Batstone, E., Fatchett, D., \& White, P. (1976). The worker directors. A sociology of participation. London: Hutchinson and Co.

Brennan, N. M., Kirwan, C. E., \& Redmond, J. (2016). Accountability processes in boardrooms: A conceptual model of manager-non-executive director information asymmetry. Accounting, Auditing \& Accountability Journal, 29(1), 135-164.

Bryant, P., \& Davis, C. (2012). Regulated change effects on boards of directors: A look at agency theory and resource dependency theory. Academy of Strategic Management Journal, 11(2), 1-15.

Bury, S., \& Leblanc, R. (2007). Corporate governance research on the free web: A selected annotated guide. Reference Services Review, 36(3), 497-514.

Cadbury, S. A. (2000). The corporate governance agenda. Corporate Governance: An International Review, 8(1), 7-15.

Charity Governance Code Steering Group. (no date). Charity governance code. Retrieved November 8 , 2019, from https://www.charitygovernancecode.org/en/front-page.

Cooren, F., Kuhn, T., Cornelissen, J. P., \& Clark, T. (2011). Introduction to the special issue: Communication, organizing and organization: An overview. Organization Studies, 32(9), 1149-1170.

Cornforth, C. (2004). The governance of cooperatives and mutual associations: A paradox perspective. Annals of Public and Cooperative Economics, 75(1), 11-32.

Crow, P., \& Lockhart, J. (2015). Is corporate governance a structure, a process, a group of policies, or something else?. In European Conference on Management, Leadership \& Governance (p. 89). Academic Conferences International Limited.

Crow, P. R., \& Lockhart, J. C. (2016). How boards influence business performance: Developing an explanation. Leadership \& Organization Development Journal, 37(8), 1022-1037.

Davis, J. H., Schoorman, F. D., \& Donaldson, L. (1997). Toward a stewardship theory of management. Academy of Management Review, 22(1), 20-47.

Deleuze, G. (1994). Difference and repetition. New York: Columbia University Press.

Durisin, B., \& Povone, F. (2009). Maturation of corporate governance research, 1993-2007: An assessment. Corporate Governance: An International Review, 17(3), 266-291.

Eisenhardt, K. M. (1989). Agency theory: An assessment and review. Academy of Management Review, 14(1), 57-74.

Fenwick, T. (2016). Social media, professionalism and higher education: A sociomaterial consideration. Studies in Higher Education, 41(4), 664-677. 
Fenwick, T., Nerland, M., \& Jensen, K. (2012). Sociomaterial approaches to conceptualising professional learning and practice. Journal of Education and Work, 25(1), 1-13.

Financial Reporting Council. (2018). Guidance on board effectiveness. London: FRC.

Freeman, T., Millar, R., Mannion, R., \& Davies, H. (2016). Enacting corporate governance of healthcare safety and quality: A dramaturgy of hospital boards in England. Sociology of Health \& Illness, 38(2), 233-251.

Freeman, T., \& Peck, E. (2007). Performing governance: A partnership board dramaturgy. Public Administration, 85(4), 907-929.

Gov.uk. (no date). The 7 principles of public life. Retrieved November 8, 2019, from https://www.gov.uk/ government/publications/the-7-principles-of-public-life.

Hendry, K. P., Kiel, G. C., \& Nicholson, G. (2010). How boards strategise: A strategy as practice view. Long Range Planning, 43(1), 33-56.

Hill, R., James, C., \& Forrest, C. (2016). The challenges facing further education college governors in England: A time for caution or creativity? Management in Education, 30(2), 79-85.

Hodges, M. (2008). Rethinking time's arrow: Bergson, Deleuze and the anthropology of time. Anthropological Theory, 8(4), 399-429.

Hough, A. D., McGregor-Lowndes, M., \& Ryan, C. M. (2010). Strategic planning as symbol: A strategy-as-practice perspective on board of director involvement in strategic planning in nonprofit organizations. Paper Presented to the Association for Research on Nonprofit Organizations and Voluntary Action Conference. November 18-20, 2010, Alexandria, VA.

Hung, H. (1998). A typology of the theories of the roles of governing boards. Corporate Governance: An International Review, 6(2), 101-111.

Huse, M. (1998). Researching the dynamics of board-Stakeholder relations. Long Range Planning, $31,218-226$.

Huse, M. (2005). Accountability and creating accountability: A framework for exploring behavioural perspectives of corporate governance. British Journal of Management, 31(2), 218-226.

Huse, M., Minichilli, A., \& Schøning, M. (2005). Corporate boards as assets for operating in the New Europe: The value of process-oriented boardroom dynamics. Organizational Dynamics, 34(3), 285-297.

Huse, M., \& Zattoni, A. (2008). Trust, firm life cycle, and actual board behavior: Evidence from" one of the lads" in the board of three small firms. International Studies of Management \& Organization, 38(3), 71-97.

James, C., Jones, J., Connolly, M., Brammer, S., Fertig, M., \& James, J. (2012). The role of the chair of the school governing body in England. School Leadership \& Management, 32(1), 3-19.

Jarzabkowski, P. (2004). Strategy as practice: Recursiveness, adaptation, and practices-in-use. Organization Studies, 25(4), 529-560.

Jarzabkowski, P., Burke, G., \& Spee, P. (2015). Constructing spaces for strategic work: A multimodal perspective. British Journal of Management, 26(1), 26-47.

Jarzabkowski, P., Lê, J., \& Spee, P. (2017). Taking a strong process approach to analyzing qualitative process data. In A. Langley \& H. Tsoukas (Eds.), The SAGE handbook of process organization studies (pp. 237-253). London: Sage.

Jørgensen, T. B., \& Sørensen, D. (2012). Codes of good governance: National or global public values? Public Integrity, 15(1), 71-96.

Judge, W. Q., \& Talaulicar, T. (2017). Board involvement in the strategic decision-making process: a comprehensive review. Annals of Corporate Governance, 2(2), 51-169.

Korac-Kakabadse, N., Kakabadse, A. K., \& Kouzmin, A. (2001). Board governance and company performance: Any correlations? Corporate Governance: The International Journal of Business in Society, 1(1), 24-30.

Kosnik, R. D. (1987). Greenmail: A study of board performance in corporate governance. Administrative Science Quarterly, 32(2), 163-185.

Langley, A., \& Tsoukas, H. (2017). Introduction. In A. Langley \& H. Tsoukas (Eds.), The SAGE handbook of process organization studies (pp. 1-26). London: Sage.

Leblanc, R. (2003). Boards of directors: An inside view. Unpublished PhD Thesis, York University, Toronto, Canada.

Leblanc, R., \& Schwartz, M. S. (2007). The black box of board processes: gaining access to a difficult subject. Corporate Governance, 15(5), 843-851.

Machold, S., \& Farquhar, S. (2013). Board task evaluation: A longitudinal field study in the UK. Corporate Governance, 21(2), 147-164. 
Maclure, M. (2005). 'Clarity bordering on stupidity': Where's the quality in systematic review? Journal of Education Policy, 20(4), 393-416.

Maitlis, S. (2004). Taking it from the top: How CEOs influence (and fail to influence) their boards. Organization Studies, 25(8), 1275-1311.

March, J. G., \& Olsen, J. P. (1975). The uncertainty of the past: Organizational learning under ambiguity. European Journal of Political Research, 3(2), 147-171.

March, J. G., \& Olsen, J. P. (1983). The new institutionalism: Organizational factors in political life. American Political Science Review, 78(3), 734-749.

McNulty, T., Zattoni, A., \& Douglas, T. (2013). Developing corporate governance research through qualitative methods: A review of previous studies. Corporate Governance: An International Review, 21(2), 183-198.

Merton, R. K. (1936). The unanticipated consequences of purposive social action. American Sociological Review, 1(6), 894-904.

Michaud, V. (2014). Mediating the paradoxes of organizational governance through numbers. Organization Studies, 35(1), 75-101.

Nicholson, G., Pugliese, A., \& Bezemer, P. (2017). Habitual accountability routines in the boardroom: How boards balance control and collaboration. Accounting, Auditing \& Accountability Journal, $30(2), 222-246$.

Nicolini, D. (2016). Is small the only beautiful? Making sense of 'large phenomena' from a practicebased perspective. In A. Hui, T. Schatski, \& E. Shove (Eds.), The nexus of practices (pp. 110-125). Abingdon: Routledge.

Parker, L. D. (2007). Internal governance in the nonprofit boardroom: A participant observer study. Corporate Governance: An International Review, 15(5), 923-934.

Parker, L. D. (2008). Boardroom operational and financial control: An insider view. British Journal of Management, 19(4), 341-374.

Peck, E. (1995). The performance of an NHS trust board: Actors' accounts, minutes and observation. British Journal of Management, 6(2), 135-156.

Peck, E., Perri, Gulliver, P., \& Towell, D. (2004). Why do we keep on meeting like this? The board as ritual in health and social care. Health Services Management Research, 17(2), 100-109.

Pettigrew, A. (1997). What is processual analysis? Scandinavian Journal of Management, 13(4), 337-348.

Pugliese, A., Nicholson, G., \& Bezemer, P. (2015a). How long shall we talk? How much shall we interact? The impact of boardroom communication patterns on board functioning. Retrieved November 8, 2019, from https://www.sciencesouthtyrol.net/blob/87620,,UNIBZ,90,61.pdf.

Pugliese, A., Nicholson, G., \& Bezemer, P. (2015b). An observational analysis of the impact of board dynamics and directors' participation on perceived board effectiveness. British Journal of Management, 26(1), 1-25.

Rescher, N. (1996). Process metaphysics: An introduction to process philosophy. New York: SUNY Press.

Roberts, J., McNulty, T., \& Stiles, P. (2005). Beyond agency conceptions of the work of the non-executive director: Creating accountability in the boardroom. British Journal of Management, 16(s1), S5-S26.

Saj, P. (2013). Charity performance reporting: Comparing board and executive roles. Qualitative Research in Accounting \& Management, 10(3/4), 347-368.

Samra-Fredericks, D. (2000a). Doing 'Boards-in-Action' Research-An ethnographic approach for the capture and analysis of directors' and senior managers' interactive routines. Corporate Governance: An International Review, 8(3), 244-257.

Samra-Fredericks, D. (2000b). An analysis of the behavioural dynamics of corporate Governance-A talk-based ethnography of a UK manufacturing 'board-in-action'. Corporate Governance: An International Review, 8(4), 311-326.

Schwartzman, H. B. (1989). The meeting. Dordrecht: Springer.

Smith, W. K., \& Lewis, M. W. (2011). Toward a theory of paradox: A dynamic equilibrium model of organizing. Academy of Management Review, 36(2), 381-403.

Sport England. (no date). A code for sports governance. Retrieved November 8, 2019, from https://www. sportengland.org/media/11193/a_code_for_sports_governance.pdf.

Sundaramurthy, C., \& Lewis, M. (2003). Control and collaboration: Paradoxes of governance. Academy of Management Review, 28(3), 397-415. 
Tacon, R., \& Walters, G. (2016). Modernisation and governance in UK national governing bodies of sport: How modernisation influences the way board members perceive and enact their roles. International Journal of Sport Policy and Politics, 8(3), 363-381.

Taylor, B. E., Holland, T. P., \& Chait, R. P. (1996). The new work of the nonprofit board. Boston: Harvard Business School Publishing.

Van Puyvelde, S., Caers, R., Du Bois, C., \& Jegers, M. (2012). The governance of nonprofit organizations: Integrating agency theory with stakeholder and stewardship theories. Nonprofit and voluntary sector quarterly, 41(3), 431-451.

Walters, G., \& Tacon, R. (2018). The 'codification' of governance in the not-for-profit sport sector in the UK. European Sport Management Quarterly, 18(4), 482-500.

Watson, C. (2019). Perspective by incongruity in the performance of dialectical ironic analysis: A disciplined approach. Qualitative Research. https://doi.org/10.1177/1468794119830073.

Watson, C., \& Drew, V. (2017). Enacting educational partnership: Collective identity, decision-making (and the importance of muffin chat). School Leadership \& Management, 37(1-2), 3-18.

Whitehead, A. N. (1929). Process and reality. New York: Harper.

Whittington, R. (1996). Strategy as practice. Long Range Planning, 29(5), 731-735.

Young, H. (2016). Asking the 'right' questions: The constitution of school governing bodies as apolitical. Journal of Education Policy, 31(2), 161-177.

Publisher's Note Springer Nature remains neutral with regard to jurisdictional claims in published maps and institutional affiliations.

Cate Watson is Professor of Educational Leadership and Professional Learning. Her research interests lie in institutional and professional identities, particularly as these relate to issues surrounding practices of leadership and governance. She is also interested in the development of humour as a methodology for the social sciences and is the author of, Comedy and Social Science. Towards a methodology of funny. (2015, Routledge).

Gary Husband is Lecturer in Professional Education and Leadership. His research is situated in further education with interests in professional learning, organisational development, leadership and governance. Gary is a governor at an adult education college.

Aileen Ireland is a postdoctoral research fellow. Her previous research interests include professional education and simulation technologies. She takes a critical approach to research, drawing on sociomaterial, posthuman and post-qualitative methodologies to decolonise understandings of knowledge production. 